Dr. E. Herzfeld, field director, which appears in the Times of February 4, says that no discovery like it has ever been made anywhere in western Asia. A magnificent series of sculptures, dating back to the time of Cyrus, has been discovered in the area of the palace burnt by Alexander the Great in 330 B.c. The size alone, without taking into account the technique and the informative detail, is overwhelmingly impressive. One panel, 5-6 ft. high, is no less than 1,000 ft. long. The carvings are as fresh as when executed and show rulers, footmen, horsemen, charioteers, servants and burden-bearers in full equipment-material of the greatest historical value. One panel preserved in peculiarly favourable circumstance still shows the colours of the royal garments. A find of no less importance to the prehistorian is recorded in an account of a stone age village which was found under a low mound within two miles of Persepolis. It is dated at about 4000 B.c. and would appear to be in an excellent state of preservation. The mud-brick walls of the houses still stand to a height of 5-7 ft. and the interior surfaces show mural paintings in red water colour. The polychrome pottery, Dr. Herzfeld reports, exceeds in beauty and age that found in Babylonia, marking "a new chapter in the history of prehistoric art".

\section{International Congress of Ethnological and Anthropological Sciences}

Considerable progress has been made in the discussion of the proposal to institute an international congress of the ethnological and anthropological sciences. Arrangements are now being made for a preliminary conference for further discussion to be held in Basel on April 20-22 next. Invitations to the conference are being issued by the Royal Anthropological Institute of Great Britain, while the local arrangements are in the hands of Dr. Felix Speiser, director of the Museum of Ethnology, Basel. The conference will be welcomed on behalf of the City and the Education Committee, and its sessions will be held in the Burgeratsaal. The subjects for discussion by the conference are the scope of the proposed congress and its relation to existing congresses of like character, such as the International Congress of Americanists and the International Congress of Prehistoric and Protohistoric Sciences; constitution and procedure; and the date and place of the first meeting. On this last point, it has been suggested that meetings should take place in years alternate to those of the Prehistoric and Protohistoric Sciences Congress and coinciding once in every four years with the European meetings of the Americanists' Congress.

\section{Insect-Eating in Siam}

INSECT-EATING habits of monkeys have persisted, and still persist, not only amongst the most primitive races of mankind, like Australian aborigines and the African pygmies, but even in many races which have reached the agricultural stage. An interesting example is offered by the Laos of Siam, whose habits of eating insects and other invertebrates have been recently studied in some detail by $\mathrm{Mr}$. W. S. Bristowe (Trans. Entom. Soc. Lond., 1932). The list of animals used as food by the Laos includes many species and exhibits a great variety, but certain of them are considered as special delicacies. Here belong, for example, giant water-bugs (Lethocerus indicus), measuring about two inches in length and fetching up to $4 d$. a piece on the markets; large spiders, Nephila maculata and Melopoeus albostriatus ('bird-eaters'); eggs of king crab, Tachypleus gigas, which look like caviare, but taste like potato ; larvæ, pupæ and adults of the dung beetles, Oryctes rhinoceros and Helicopris sp.; a large cicada, Dundubia intemerata; etc. There is no reason to think that insect-eating habits of the Laos were acquired owing to the lack of other food, since the Siamese living under the same conditions do not eat insects to such a great extent. On the other hand, it is interesting to note that the Laos are considered to possess greater stamina and to be harder workers than the Siamese; this may be due to the extra protein obtained by the Laos from their animal food. The average diet of a Siamese includes fish as practically the only source of protein; the protein content of fish is 18-23 per cent, and that of roasted spiders is so high as $63 \cdot 4$ per cent.

\section{Fauna of the Swiss National Park}

The area of mountain, forest and valleys comprising the Nature reserve which forms the Swiss National Park is a tract of country that is rigidly preserved. Its fauna and flora are subjected to the minimum of interference on the part of man and for this reason afford many problems of special interest to the biologist. Under the auspices of the commission for the scientific investigation of the Swiss National Park, a series of quarto memoirs on researches undertaken in that area is being published. The sixth memoir in that series has recently come to hand and deals with the forest insects of the Park ("Les Insectes Forestiers du Parc National Suisse". Pp. $50+24$ plates. Aarau : H. R. Sauerländer et Cie. 12 francs). Its author, Dr. Aug. Barbey, mentions that the circumstances in which these insects were studied were purely economic and were in connexion with the ravages they cause among the forest trees. The life-history, mode of life and economic status of the more important species of insects are described. Various stages in their lifecycle, their larval burrows in wood and bark and other phases of these insects are admirably portrayed in the series of plates that accompany this memoir. Their ecological relations are also dealt with whether they be destructive forms, parasites or predators.

\section{Reduction of Chimney Emissions}

THE Technical Committee appointed by the Electricity Commissioners in 1930 to consider the methods that should be taken to prevent the emission of soot, ash and grit from the chimneys of electric power stations has now published its report (London : H.M. Stationery Office, 5s.). A sub-committee made 